\title{
Ore Geology of Skarn Ore Bodies in the Kasihan Area, East Java, Indonesia
}

\author{
Jin-Kyun Han ${ }^{1}$ and Sang-Hoon $\mathrm{Choi}^{2 *}$ \\ ${ }^{1}$ Daewoo International, Seoul, Korea \\ ${ }^{2}$ Department of Earth and Environmental Sciences, Chungbuk National University, Cheongju 361-763, Korea
}

\section{인도네시아 까시한지역 스카른광체의 광상학적 특성}

\author{
한진균 ${ }^{1} \cdot$ 최상훈 ${ }^{2 *}$ \\ ${ }^{1}$ 대우인터내셔널, ${ }^{2}$ 충북대학교 지구환경과학과
}

인도네시아 까시한 지역 함 동-아연 스카른광체는 올리고신 후기 퇴적암류 중 석회암층을 따라 발달한다. 스카른광체 의 괴상스카른대는 초기에서 후기로 단사휘석-석류석대, 석류석대, 석류석-녹염석대, 녹염석대 스카른으로 구분된다. 초기 괴상 스카른대에서 산출하는 단사휘석은 투휘석-헤덴버가이트 고용체로서, 초기 투휘석 단성분에 가까운 조성으로부터 후기 salitic 단사휘석으로의 조성변화가 확인된다. 이러한 단사휘석의 조성변화는 일반적인 스카른 광체에서의 수반 금 속성분 $(\mathrm{Cu}$ 및 $\mathrm{Zn}$ 광화작용)과 단사휘석 조성 상관관계와 잘 일치한다. 석류석의 경우 그로슐라-안드라다이트 고용체로 서 매우 넓은 조성변화를 보여주며, 후기 석류석의 경우 $\mathrm{Fe}$ 함량의 증가 경향성이 인지된다. 녹염석의 경우 클리노조이사 이트-피스타사이트 고용체(65.8-76.2 mol. \% 클리노조이사이트)로 확인된다. 상평형관계로 확인된 까시한 지역 함 동-아 연 스카른광체는 약 $0.5 \mathrm{~kb}$ 의 환경에서 초기 약 $450^{\circ} \mathrm{C}$ (단사휘석-석류석 및 석류석 스카른, $\approx 450-370^{\circ} \mathrm{C}$ ) 에서 시작되어 후기 $300^{\circ} \mathrm{C}$ (석류석-녹염석 및 녹염석 스카른, $\approx 370-300^{\circ} \mathrm{C}$ ) 에 걸쳐 진행되었다.

주요어 : 함 동-아연 스카른, 단사휘석, 석류석, 까시한 지역, 인도네시아

Copper-zinc-bearing skarns of the Kasihan area developed at limestone layers in the sedimentary facies of the Late Oligocene Arjosari Formation. The skarns consist mainly of fine-grained, massive clinopyroxene-garnet, garnet, garnet-epidote, and epidote skarns. Most copper and zinc(-lead) ore mineralization occur in the clinopyroxene-garnet and garnetepidote skarn, respectively. Clinopyroxene occurs as a continuous solid solution of diopside and hedenbergite (from nearly pure diopside up to $\approx 34$ mole percent hedenbergite), with a maximum 28.2 mole percent johannsenite component. The early and late pyroxenes of Kasihan skarns are diopsidic and salitic, respectively. They fall in the fields typical $\mathrm{Cu}-$ and Zn-dominated skarns, respectively. Garnet displays a relatively wide range of solid solution between grossular and andradite with up to $\approx 2.0$ weight percent $\mathrm{MnO}$. Garnet in early pyroxene-garnet skarn ranges from 49.1 to 91.5 mole percent grossular (mainly $\geq 78$ mole \% grossular). Garnets in late garnet and garnet-epidote skarns range from 2.8 to 91.4 mole percent grossular (mainly $\geq 70$ mole $\%$ for garnet skarn). Epidote compositions indicate solid solutions of clinozoisite and pistacite varying from 65.8 to 76.2 mole percent clinozoisite. Phase equilibria indicate that skarn evolution was the result of interaction of water-rich fluids $\left(\mathrm{X}_{\mathrm{CO}_{2}} \leq 0.1\right)$ with original lithologies at $\approx 0.5 \mathrm{~kb}$ with declining temperature (early clinopyroxene-garnet and garnet skarn, $\approx 450$ to $370^{\circ} \mathrm{C}$; late garnet-epidote and epidote skarn, $\approx 370$ to $300^{\circ} \mathrm{C}$ ).

Key words : copper-zinc bearing skarns, clinopyroxene, garnet, Kasihan area, Indonesia

\section{Introduction}

The Kasihan area lies on the Pacitan district of the south western portions in the East Java, near the boundary of central Java (Fig. 1). Extensive basemetal and/or gold bearing skarn and hydrothermal

*Corresponding author: cshoon@ chungbuk.ac.kr 


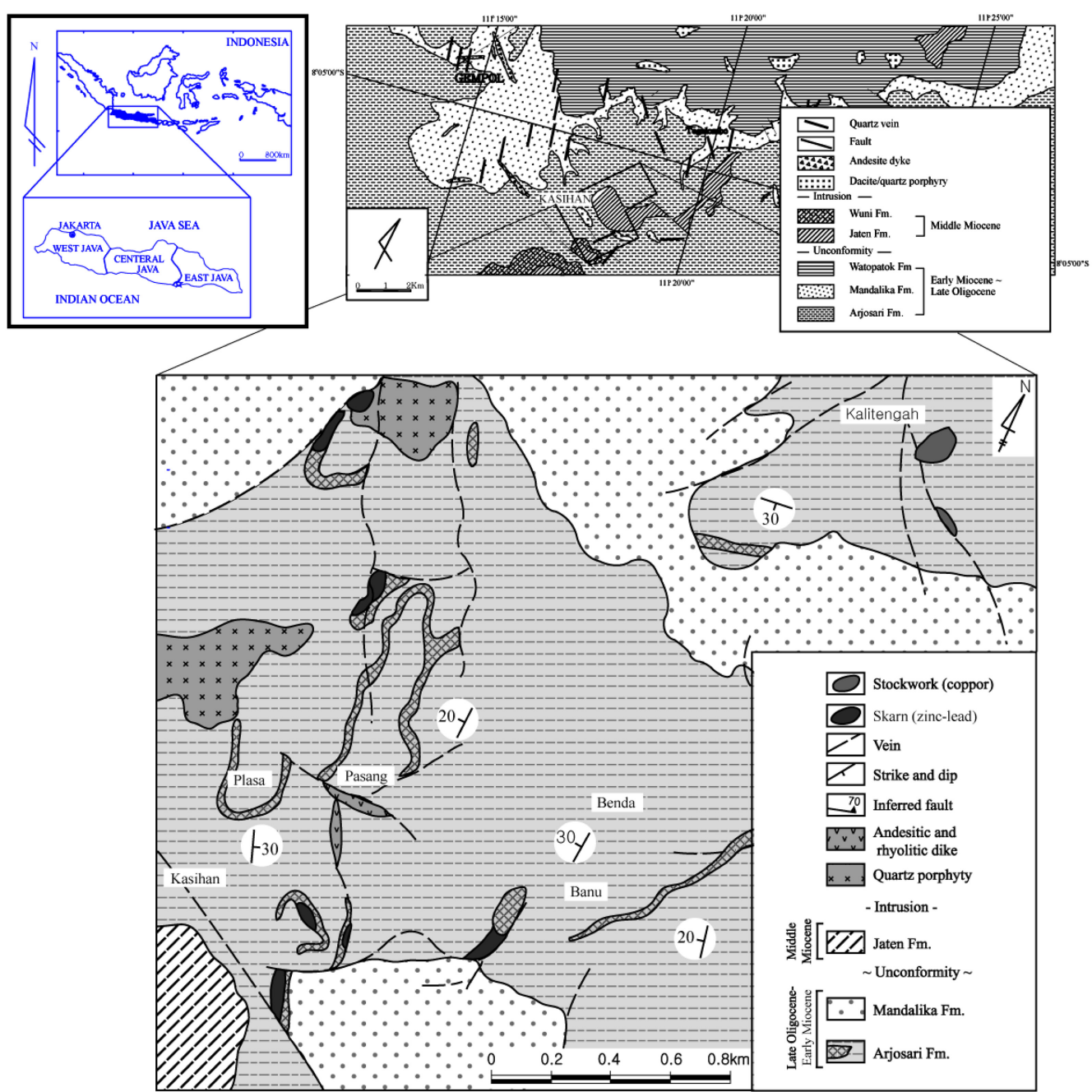

Fig. 1. Geologic map of the Kasihan area, and star symbol represents the location of the area.

mineralizations have been found recently at the Kasihan area, Pacitan district of East Java, Indonesia. These are the new discoveries of base-metal (and/ or gold) occurrences made in the district, and the results of the new prospecting work undertaken during 1991-1993 in the area by the Joint Mineral Exploration between Korea Mining Promotion Corporation (KMPC), Korea. The Kasihan area consists of mixed sequences of Tertiary to Quaternary sedimentary and volcanic rocks (Fig. 1). A number of skarns, and hydrothermal stockworks and veins containing mainly copper, zinc, lead and/or gold occur within the sedimentary and volcanic rocks of Oligocene and Miocene age. Copper-zinc(-lead)- bearing skarn and copper-bearing stockwork occur in the Kasihan area. The skarns consist of several vertically stacked orebodies that developed at limestone layers in the sedimentary facies.

In this study, the history of skarn formation and copper-zinc mineralization at the Kasihan area is reconstructed, with particular emphasis on the variations, in time and space, of the mineralogies of the skarns and their chemical compositions.

\section{Geology}

The geology of the Kasihan area within the Pacitan district on the Southern mountain zone of 
the southwestern margin of East Java is shown on the geologic map in Fig. 1. Rocks of the Pacitan district mainly consist of a mixed sequence of sedimentary rocks intercalated with lavas and volcaniclastic rocks (Van Bemmelen, 1949). These rocks are divided into the Late Oligocene to Early Miocene Arjosari, Mandalika and Watupatok Formation, and the Middle Miocene Jaten and Wuni Formation. The younger igneous rocks intrude the above formations and range in composition from dacite to andesite. A number of small porphyritic intrusions and andesitic dykes ubiquitously intrude the above mentioned volcanics and sedimentary rocks.

The geology of the Kasihan area consists of sedimentary rocks of the Arjosari, Mandalika and Jaten Formation, and quartz porphyry as younger intrusive (Fig. 1).

The Arjosari Formation, the lowermost unit in the Kasihan area, largely exposed in the area. The Formtion consists of upwardly fining polymict conglomerate-sandstone-siltstone-mudstone sequences. It is interbedded with limestone which occurs as lenticular and/or thin bed with poor lateral continuity. These sedimentary rocks represent marine sedimentary facies deposited in shallow sea and/or lagoon environments.

The Mandalika Formation, which occupies widely in the north and south margin portions of the area, has a volcanic and sedimentary facies overlying conformably the Arjosari Formation. It divided into two rock members; volcanic-sedimentary facies in lower part, and volcanic facies in upper part.

The Jaten Formation of Middle Miocene, which overlies unconformably the Arjosari and Mandalika Formation, consists of polymictic conglomerate, tuffaceous sandstone, mudstone, lignite, carbonaceous shale and tuff.

A number of small porphyritic intrusions of dacitic to andesitic compositions crop out within the west and north portions of the area. As most of these intrusives occur within Late Oligocene to Early Miocene sediments, a Middle Miocene or younger age is inferred. The ore mineralization in the district is likely to be associated with quartz porphyry.

\section{Skarns}

The skarns in the Kasihan area consist of several vertically stacked orebodies that developed at limestone layers in the sedimentary facies of the Arjosari Formation (Fig. 1). In detail, spatial distribution of skarns reflects original lithologies and a complex overlapping series of veins that developed during periods of metasomatism. Where fluids moved along fractures and other secondary structures that transect bedding, limestone was replaced at relatively greater distances from the igneous rock. The skarns are characterized with relatively finegrained pyroxene, garnet and epidote. The ore mineralization in the skarns represents mainly zinc (-lead) with copper mineralization.

Skarn types originating from limestone consist mainly of fine-grained, massive clinopyroxene-garnet, garnet, garnet-epidote, and epidote skarns. These skarns consist mainly of clinopyroxene, garnet, epidote, and quartz with minor amounts of chlorite, biotite, muscovite, siderite and calcite. Garnetepidote skarn formed intermediate to clinopyroxenegarnet and epidote skarns grades into epidotechlorite skarn. It is greenish brown in color and composed mainly of garnet and epidote with minor amounts of quartz, calcite, biotite and chlorite. Most zinc(-lead) ore mineralization occurs in the garnet-epidote skarn.

Clinopyroxene occurs mainly in clinopyroxenegarnet skarn and are 0.01 to $0.5 \mathrm{~cm}$ in length. Clinopyroxene is subhedral to anhedral in shape and is frequently altered along cleavage. Garnet exhibits a wide range in color from pale brown to dark brown, but there is little or no correlation between color and major element composition.

Garnet, which occurs mainly in garnet and garnetepidote skarns, is grossularitic and weakly to strongly anisotropic. Garnet tends to occur in subhedral polycrystalline aggregates and rarely exhibits optical zoning, which parallels with crystal faces. Coarsegrained euhedral garnet crystals are filled with epidote, quartz, ore minerals and rarely clinopyroxene, and are often altered to epidote and chlorite. It contains locally acicular calcite and rhodochrocite. Garnet in garnet-epidote and epidote skarn is partly to almost light color (pale brown) and has a relatively optically homogeneous core.

Epidote is present locally in all skarns, but is more abundant in garnet-epidote and epidote skarn. It occurs as partial replacement of anisotropic garnet and medium- to coarse-grained aggregates 
associated intimately with quartz and Fe-oxide minerals. Calcite, rhodochrocite, dolomite and siderite as carbonates are characteristic of later skarn mineralization.

\subsection{Skarn Mineral Compositions}

Chemical compositions of clinopyroxene, garnet and epidote from the Kasihan skarn orebodies were determined using JXA-8600 electron microprobe at the Center for Mineral Resources Research, Korea University. Determined concentrations were corrected for matrix effects using the method of ZAF (Bence and Albee, 1968).

Clinopyroxene: Clinopyroxene is the most abundant mineral in the early massive skarn at Kashian. It occurs as a continuous solid solution of diopside and hedenbergite (from nearly pure diopside up to 34 mole percent hedenbergite), with a maximum 28.2 mole percent johannsenite component (Table 1, Fig. 2). The johannsenite content generally increases with increasing hedenbergite content. There are two compositional populations of clinopyroxene: 1) early pyroxenes represent nearly pure diopsidic compositions; 2) late pyroxenes are salitic compositions (Fig. 2). Most copper ore mineralization at Kashian skarn orebodies occurs in the early clinopyroxene skarn. In general, there is a relationship between the composition of pyroxenes of the skarn facies

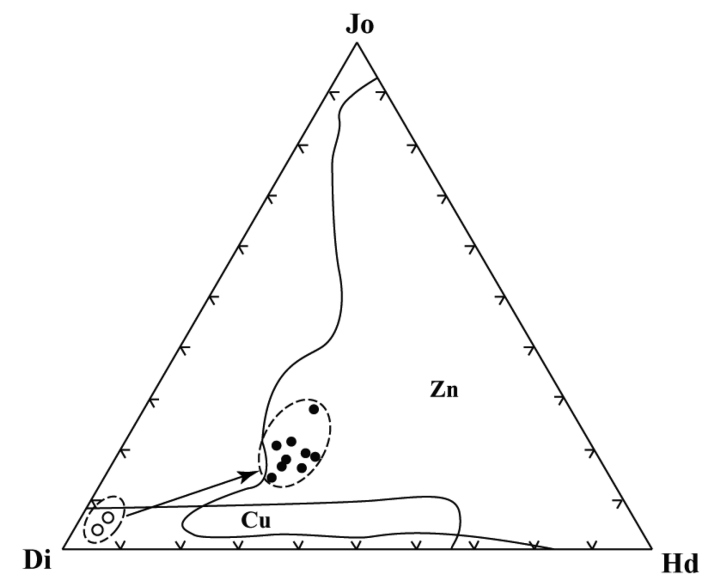

Fig. 2. Compositions of clinopyroxenes in massive skarns at the Kasihan area. Open circle represents early clinopyroxenes related to $\mathrm{Cu}$-dominent mineralization, and closed circle represents late clinopyroxenes related to $\mathrm{Zn}$-dominent mineralization. Abbreviations: $\mathrm{Di}=$ diopside, $\mathrm{Hd}=$ hedenbergite, $\mathrm{J}_{\mathrm{O}}=$ johannsenite and the dominant metal of the mineralized skarns (Einaudi et al., 1981, Einaudi and Burt, 1982, Malo et al., 2000). The early and late pyroxenes of Kasihan skarns are diopsidic and salitic, respectively. They fall in the fields typical $\mathrm{Cu}$ - and $\mathrm{Zn}$-dominated skarns, respectively (Fig. 2). Chemical compositions of clinopyroxene seem to indicate a continuous iron and manganese enrichment of the metasomatic fluids with increasing time in the skarn-forming event.

Garnet: Garnet is the most abundant mineral in the various skarn assemblages at Kasihan skarn orebodies. It displays a relatively wide range of solid solution between grossular and andradite with up to $\approx 2.0$ weight percent $\mathrm{MnO}$ (Table 2 and Fig. 3). Garnet in early pyroxene-garnet skarn is anhedral, isotropic to weakly anisotropic, and are often associated with fine-grained clinopyroxene. Their compositions range from 49.1 to 91.5 mole percent grossular (mainly $\geq 78$ mole $\%$ grossular) and contain up to 1.5 weight percent $\mathrm{MnO}$ and $\leq 0.6$ weight percent $\mathrm{TiO}_{2}$. By contrast, garnet in garnet and garnet-epidote, and epidote skarns associated with quartz, epidote and calcite, is euhedral, strongly anisotropic and display relatively wide compositional range. These garnets range from 2.8 to 91.4 mole percent grossular (mainly $\geq 70$ mole $\%$ for garnet skarn) and contain up to $\approx 3.5$ weight percent $\mathrm{MnO}$ and $<1.2$ weight percent $\mathrm{TiO}_{2}$. Chemical compositions of garnet seem to indicate

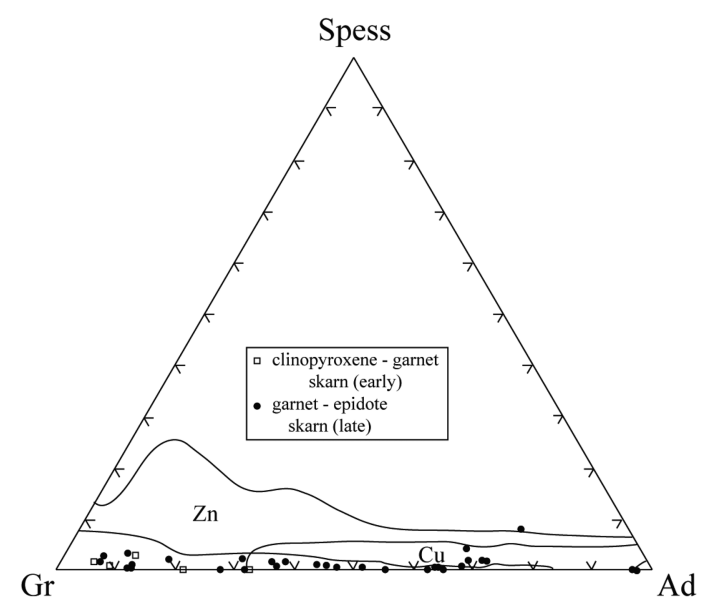

Fig. 3. Compositions of garnets in massive skarns at the Kasihan area. Abbreviations: $\mathrm{Ad}=$ andradite, $\mathrm{Gr}=$ grossular, Spess $=$ spessartine + pyrope + uvarovite. 


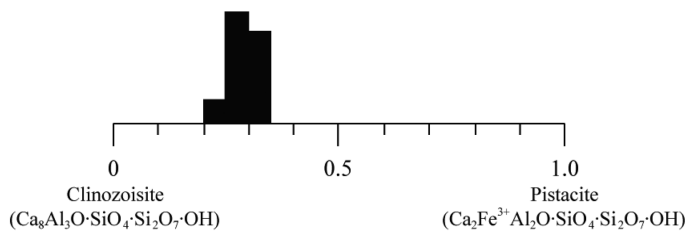

Fig. 4. Compositions of epidotes in massive skarns at the Kasihan area.

a continuous iron enrichment of the metasomatic fluids with increasing time in the skarn-forming event.

Epidote: Epidote is present from garnet to epidote skarns, but is most abundant in epidote skarn. It occurs as: 1) partial replacement of anisotropic garnet in garnet skarns; 2) disseminated grain in garnet-epidote skarns; 3) medium- to coarse-grained aggregates associated intimately with quartz and calcite in epidote skarns. Epidote compositions indicate solid solutions of clinozoisite and pistacite (Table 3 and Fig. 4) varying from 65.8 to 76.2 mole percent clinozoisite.

\section{Ore Mineralization}

Ore mineralization in the skarn orebodies is of a hydrothermal metasomatic origin and represent mainly $\mathrm{Zn}(-\mathrm{Pb})$ with $\mathrm{Cu}$ mineralization. The ore mineralogy is relatively simple. Base-metal sulfides, Fe-oxides, and rare sulfosalts typically fill interstices between or replace skarn minerals, and occur mainly as massive and locally disseminations. The ore mineralization may be divided broadly into two groups based on average grades of $\mathrm{Cu}, \mathrm{Zn}$ and $\mathrm{Pb}$, and mineral assemblage: proximal stage, copper-iron mineralization; distal stage, zinc(-lead) mineralization. Ore mineralization of proximal stage is characterized by chalcopyrite, bornite and hematite (skarn type) as copper-iron mineralization. Distal stage consists mainly of sphalerite and galena (skarn type) as $\mathrm{Zn}(-\mathrm{Pb})$ mineralization with magnetite and hematite.

\subsection{Mineralogy and Paragenesis}

The skarn orebodies represent $\mathrm{Cu}-\mathrm{Zn}(-\mathrm{Pb})$ ore mineralization within skarn minerals and relatively simple ore mineralogy. Ore mineralization at the skarn orebodies occurs within the various skarn mineral assemblages. The ore minerals typically

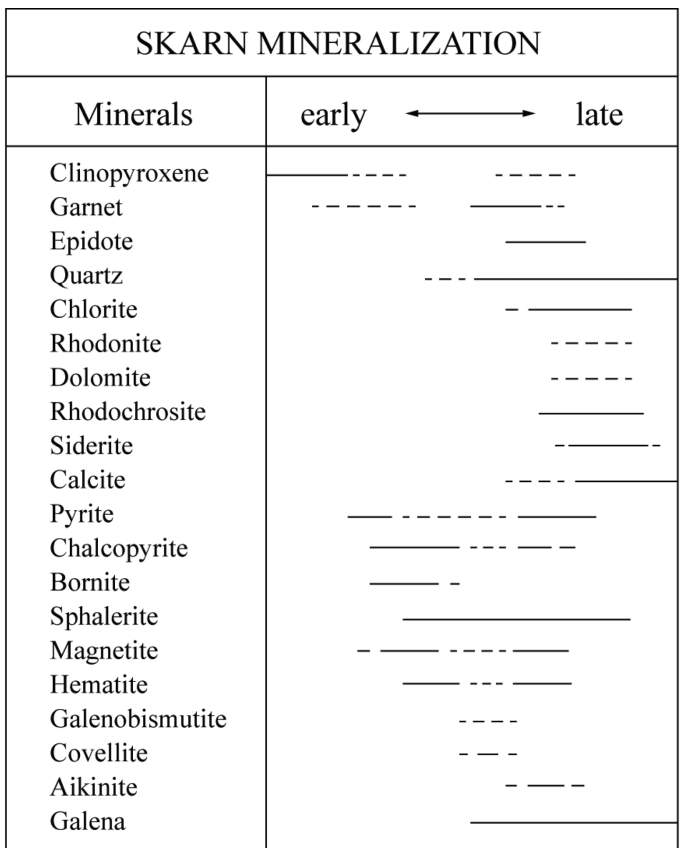

Fig. 5. Generalized paragenetic sequence of ore and skarn minerals in skarn ore bodies, Kasihan area.

fill interstices between or replace clinopyroxene, garnet, epidote, chlorite, quartz and carbonates. The mineral paragenesis shown in Fig. 5, represents spatial as well as temporal relationships of the ore and skarn minerals.

Skarn-hosted ore mineralizations are characterized by deposition of sulfides and Fe-oxides with minor amounts of sulfosalts. Ore minerals occur as massive and fine disseminations in the skarns. Early skarnhosted ore mineralization is characterized by chalcopyrite and/or bornite as copper mineralization, and massive magnetite and hematite as Fe-oxide mineralization with euhedral pyrite which occur mainly in clinopyroxene-garnet and garnet skarns. Late skarn-hosted ore mineralization is characterized by sphalerite and/or galena as $\mathrm{Zn}(-\mathrm{Pb})$ mineralization with pyrite and rare sulfosalts.

Pyrite is a relatively common constituent of skarnhosted ores, occurring as coarse-grained euhedral to subhedral crystals (early pyrite) and fine crystalline aggregates (late pyrite). It is commonly fractured, and cemented or replaced by chalcopyrite, sphalerite and galena.

Chalcopyrite is distributed widely throughout the paragenesis: 1) with bornite as exsolutions or 
intergrowth and replacement products; 2) partly enclosed in pyrite and sphalerite or as tiny veinlets cutting pyrite and sphalerite; and 3) as exsolutions in sphalerite. Most chalcopyrites occur as massive in clinopyroxene-garnet skarn.

Bornite occurs as anhedral masses associated with chalcopyrite and covellite. It includes covellite as inclusions.

Magnetite and hematite as Fe-oxide mineralization are relatively common constituents of skarn-hosted ores. These are distributed widely throughout the paragenesis: 1) as exsolutions or intergrowths in the early sulfides, 2) forming massive orebodies associated with each other and 3) as intergrowths with sphalerite and/or galena. Late hematite occurs mainly as euhedral specularite.

Sphalerite, which does not show the variation of FeS contents with paragenetic time, is also distributed widely throughout the paragenesis. The FeS contents in sphalerite range from 1.9 to 4.9 mole percent. The main sphalerite mineralization occurs in garnet and garnet-epidote skarns.

Galena occurs as anhedral masses frequently associated with sphalerite. Galenobismutite and aikinite occur as anhedral grains associated or replaced within chalcopyrite, pyrite and sphalerite.

\section{Physicochemical Environments of Skarn Formation}

The small number of phases formed at any one time in skarns makes it difficult to determine the intensive variables of skarn-forming environments. Anhydrous assemblages formed in the early skarn consist of simple phases. This indicates that variations in early skarn stage mineralogy reflect progressive changes in compositions of skarn-forming fluids caused by their reaction with host rocks as they migrated through the system. Complex calc-silicate assemblages are formed later, during hydrous destruction of earlier-formed anhydrous assemblages. The high variance of these later assemblages can be attributed to the activity of externally controlled factors.

To determine the general environments of skarn formation in Kasihan, it is necessary to consider the effects of temperature (T) and fluid composition $\left(\mathrm{X}_{\mathrm{CO}_{2}}\right)$, and oxygen fugacity $\left(\mathrm{f}_{\mathrm{O}_{2}}\right)$.

\subsection{Temperature - Fluid Composition Constraints}

Fig. 6 is a $\mathrm{T}-\mathrm{X}_{\mathrm{CO}_{2}}$ diagram constructed for a pressure of $0.5 \mathrm{~kb}$ showing mineral equilibria applicable to skarn assemblages at skarn deposits in Kasihan. Fluid inclusion data indicate that the hydrothermal vein mineralization in the Kasihan area may occurs at about 300 bars as maximum depth (Choi et al., 1995). The skarn mineralization developed on limestone layers in the lower sedimentary rock member of the Arjosari Formation, whereas the hydrothermal mineralization occurs in the upper sedimentary rock member of the Mandalika Formation and/or the Jaten Formation. Therefore, the pressure for skarn formation in this area is relatively high and an estimated $0.5 \mathrm{~kb}$. The presence of grossularitic garnet together with quartz, the presence of diopsidic pyroxene instead of forsterite or tremolite, and especially, the absence of

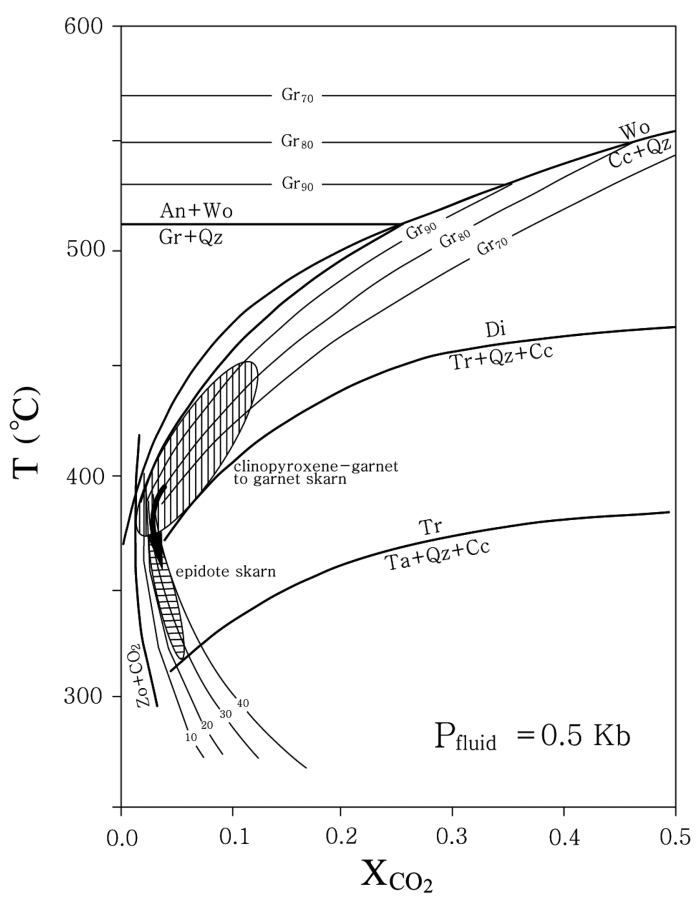

Fig. 6. Temperature $(\mathrm{T})-X_{\mathrm{CO}_{2}}$ diagram at $0.5 \mathrm{~kb}$ showing the general environment of skarn evolution (from early clinopyroxene-garnet and garnet skarn to late epidote skarn, indicated by arrows) at Kasihan area. Calc-silicate equilibria based on the experimental work of Gorden and Greenwood (1971), Greenwood (1967), Huang (1976), Newton (1966), and Slaughter et al. (1975). Abbreviations: $\mathrm{An}=$ anorthite, $\mathrm{Cc}=$ calcite, $\mathrm{Gr}=$ grossular, $\mathrm{Qz}=$ quartz, $\mathrm{Ta}=\mathrm{talc}, \mathrm{Tr}=$ tremolite, $\mathrm{Wo}_{\mathrm{O}}=$ wollastonite, $\mathrm{Zo}=$ zosite. 
wollastonite and anorthite provide constraints on conditions of early skarn formations (clinopyroxene - garnet and garnet skarn). The common occurrence of calcite and quartz, and the absence of wollastonite in calc-silicate skarns in Kasihan indicates that the reaction (1) Wollastonite $+\mathrm{CO}_{2}=$ Calcite + Quartz is an upper temperature and lower $\mathrm{X}_{\mathrm{CO}_{2}}$ limit for early skarns. The reaction (2) 5 Diopside $+3 \mathrm{CO}_{2}+$ $\mathrm{H}_{2} \mathrm{O}=$ Tremolite +3 Calcite + 2Quartz establishes a general lower temperature limit because diopside is a common phase. Consideration of the effect of andradite solid solution on grossularite stability in the reactions (3) Grossular + Quartz $=$ Anorthite + 2Wollastonite and (4) Grossular $+2 \mathrm{CO}_{2}=$ Anorthite +2 Calcite + Quartz further defines the conditions of metasomatism (Kerrick, 1974; Taylor and Liou, 1978). As suggested by Mueller (1973), these equations can be combined with standard thermodynamic data for entropy, enthalpy, and molar volume (Robie et al., 1978), using an ideal solution model to calculate temperature shifts at 500 bars for specific grandite compositions relative to the experimentally determined end-member equilibria (Greenwood, 1967). The calculated temperature shifts for reaction (3) in 10 mole percent andradite increments and consequent shifts of the invariant point intersection of reactions (3) and (4) are shown in Fig. 6. Using the 10 mole percent andradite component in early garnet and increasing tendency of mole percent andradite component with increasing time in skarnforming event of Kasihan results in a restricted environment of early skarn formation. These indicate that the early skarn formed at temperatures about $450^{\circ}$ to $370^{\circ} \mathrm{C}$ from fluids with $\mathrm{X}_{\mathrm{CO}_{2}}$ less than about 0.1 .

During the late skarns (garnet-epidote and epidote skarn) contain epidotes as aluminous as 20 to 35 mole percent pistacite. Equilibrium curves for the reaction Zoisite $+\mathrm{CO}_{2}=$ Anorthite + Calcite $+\mathrm{H}_{2} \mathrm{O}$ contoured for pistacite content indicate conditions of the late skarn formation of temperature about $370^{\circ}$ to $300^{\circ} \mathrm{C}$ and $\mathrm{X}_{\mathrm{CO}_{2}}$ less than about 0.1 (Fig. 6).

\subsection{Temperature-Oxygen Fugacity Conditions}

Stability fields of the skarns in Kasihan may be discussed as functions of oxygen fugacity $\left(\mathrm{f}_{\mathrm{O}_{2}}\right)$ and temperature (Fig. 7) utilizing $\mathrm{X}_{\mathrm{CO}_{2}}$ conditions determined earlier (Fig. 6). The absence of visible liquid $\mathrm{CO}_{2}$ in fluid inclusions in skarn and phase

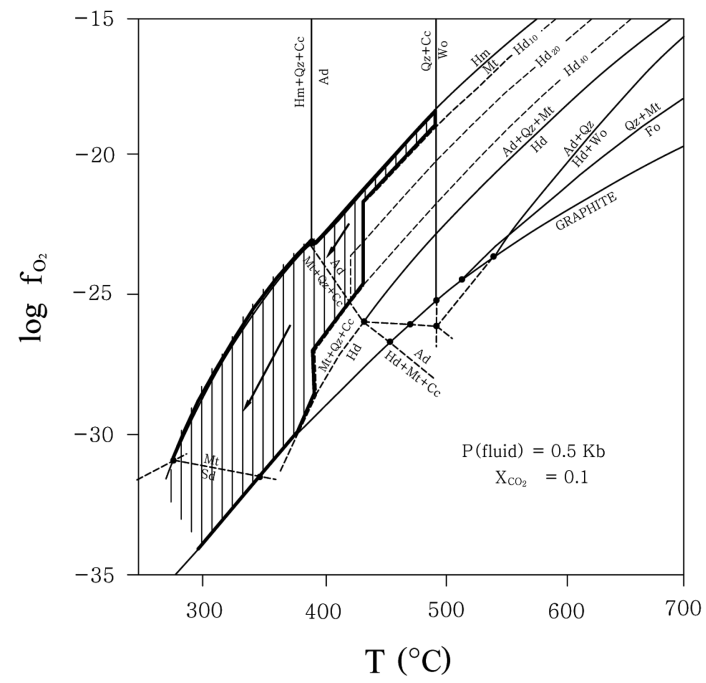

Fig. 7. Temperature $(\mathrm{T})-f_{\mathrm{O}_{2}}$ diagram at $0.5 \mathrm{~kb}$ showing the general environment of skarn formation (ruled area) at Kasihan area, modified from Liou (1974). Reactions are from Gorden and Greenwood (1971), Greenwood (1967), Gustafson (1974), and Taylor and Liou (1978). The stability field of siderite at $\mathrm{X}_{\mathrm{CO}_{2}}=0.1$ is based on the experimental data from French (1971). Abbreviations: $A d=$ andradite, $\mathrm{Cc}=$ calcite, $\mathrm{Fo}=$ forsterite, $\mathrm{Hd}=$ hedenbergite, $\mathrm{Hm}=$ hematite, $\mathrm{Mt}=$ magnetite, $\mathrm{Qz}=$ quartz, $\mathrm{Sd}=$ siderite, $\mathrm{Wo}=$ wollastonite.

relations (Fig. 7) indicate a mean $\mathrm{X}_{\mathrm{CO}_{2}} \approx 0.1$. The absence of graphite in skarn assemblages provides a lower limit of $\mathrm{f}_{\mathrm{O}_{2}}$. The absence of wollastonite and hematite, and the presence of magnetite with common occurrence of quartz in early clinopyroxenegarnet skarns are an upper limits of $\mathrm{f}_{\mathrm{O}_{2}}$. The increasing trend of mole percent hedenbergite from about 5 mole percent to 40 mole percent and the common occurrence of siderite and calcite in late skarn further define the lower $\mathrm{f}_{\mathrm{O}_{2}}$ conditions for late skarn formation. Resulting conditions of skarn formation from these reactions are $\mathrm{f}_{\mathrm{O}_{2}}$ about $10^{-18}$ to $10^{-34}$ bars (Fig. 7).

\section{Discussion and Conclusion}

The skarns in the Kasihan area consist of several vertically stacked orebodies that developed at limestone layers in the sedimentary facies of the Arjosari Formation. Where fluids moved along fractures and other secondary structures that transect bedding, limestone was replaced at relatively greater distances from the igneous rock. The ore 
mineralization in the skarns represents mainly zinc(-lead) with copper mineralization. Skarn types originating from limestone consist mainly of finegrained, massive clinopyroxene-garnet, garnet, garnetepidote, and epidote skarns. These skarns consist mainly of clinopyroxene, garnet, epidote, and quartz with minor amounts of chlorite, biotite, muscovite, siderite and calcite.

Clinopyroxene occurs as a continuous solid solution of diopside and hedenbergite (from nearly pure diopside up to $\approx 34$ mole percent hedenbergite), with a maximum 28.2 mole percent johannsenite component. There are two compositional populations of clinopyroxene: 1) early pyroxenes represent nearly pure diopsidic compositions; 2) late pyroxenes are salitic compositions. The early and late pyroxenes of Kasihan skarns are diopsidic and salitic, respectively. They fall in the fields typical $\mathrm{Cu}$ - and Zn-dominated skarns, respectively. Garnet displays a relatively wide range of solid solution between grossular and andradite with up to $\approx 2.0$ weight percent $\mathrm{MnO}$. The compositions of garnet in early pyroxene-garnet, and in late garnet-epidote skarns range from 49.1 to 91.5 mole percent and from 2.8 to 91.4 mole percent grossular, respectively.

Phase equilibria indicate that skarn evolution was the result of interaction of water-rich fluids $\left(\mathrm{X}_{\mathrm{CO}_{2}} \leq 0.1\right)$ with original lithologies at $\approx 0.5 \mathrm{~kb}$ with declining temperature (early clinopyroxenegarnet and garnet skarn, $\approx 450$ to $370^{\circ} \mathrm{C}$; late garnet-epidote and epidote skarn, $\approx 370$ to $300^{\circ} \mathrm{C}$ ) with $\mathrm{f}_{\mathrm{O}_{2}}$ about $10^{-18}$ to $10^{-34}$ bars.

\section{Acknowledgements}

This work was supported by the research grant of the Chungbuk National University in 2010. The authors thank the survey team members who participated in the Joint Mineral Exploration Project. We wish to thank for Korea Resources Corporation for providing assistance during the exploration.

\section{References}

Bence, A.E. and Albee, A.L. (1968) Empirical correction factors for the electron microanalysis of silicates and oxides. J. Geol., v.76, p.382-403.

Choi, S.G., So, C.S., Choi, S.H. and Han, J.K. (1995)
Genetic environments of hydrothermal vein deposits in the Pacitan District, East Java, Indonesia. Econ. Environ. Geol., v.28, p.109-121.

Einaudi, M.T. and Burt, D.M. (1982) Introduction: terminology, classification, and composition of skarn deposits. Econ. Geol., v.77, p.745-754.

Einaudi, M.T., Meinert, L.D. and Newberry, R.J. (1981) Skarns deposits. Econ. Geol., $75^{\text {th }}$ Anniversary Volume, p.317-391.

French, B.M. (1971) Stability relations of siderite $\left(\mathrm{FeCO}_{3}\right)$ in system Fe-C-O. Am. Jour. Sci., v.271, p.37-38.

Gordon, T.M. and Greenwood, H.J. (1971) The stability of grossularite in $\mathrm{H}_{2} \mathrm{O}-\mathrm{CO}_{2}$ mixtures. Amer. Mineral., v.56, p.1674-1688.

Greenwood, H.J. (1967) Wollastonite: Stability in $\mathrm{H}_{2} \mathrm{O}-\mathrm{CO}_{2}$ mixtures and occurrence in a contact metamorphic aureole near Salmo, British Columbia, Canada. Am. Mineral., v.52, p.1669-1680.

Gustafson, W.I. (1974) The stability of andradite, hedenbergite, and related minerals in the system Ca-Fe-Si-OH. J. Petrology, v.15, p.455-496.

Huang, C. (1976) An isotopic and petrologic study of the contact metamorphism and metasomatism related to copper deposits at Ely, Nevada: Unpub. Ph. D. Dissert., The Pennsylvania State Univ., 178p.

Kerrick, D.M. (1974) Review of metamorphic mixed-volatile $\left(\mathrm{H}_{2} \mathrm{O}-\mathrm{CO}_{2}\right)$ equilibria. Am. Miner., v.59, p.729762.

Liou, J.G (1974) Stability realtions of anorthite-quartz in the system Ca-Fe-Si-O-H: Am. Minerl., v.59, p.10161025 .

Malo, M., Moritz, R., Dube, B., Chagnon, A., Roy, F. and Pelchat, C. (2000) Base metal skarns Au occurrences in the Southern Gaspe Appalachians: distal products of a faulted and displaced magmatic-hydrothermal system along the Grand Pabos-Restigouche fault system. Econ. Geol., v.95, p.1297-1318.

Mueller, R.F. (1973) System $\mathrm{CaO}-\mathrm{MgO}-\mathrm{SiO}_{2}-\mathrm{C}-\mathrm{H}_{2}-\mathrm{O}_{2}$ : Some correlations from nature and experiment: Am. Jou. Sci., v.273, p.152-170.

Newton, R.C. (1966) Some calc-silicate equilibrium relations. Amer. J. Sci., v.264, p.204-222.

Robie, R.A., Hemingway, B.S. and Fisher, J., J.R. (1978) Thermodynamic properties of minerals and realted substances at $298.15^{\circ} \mathrm{K}$ and 1 bar $\left(10^{5}\right.$ pascals) pressure and at higher temperatures: U.S. Geol. Survey Bull., v.1452, 456p.

Slaughter, J., Kerrick, D.M. and Wall, W.J. (1975) Experimental and thermodynamic study of equilibria in the system $\mathrm{CaO}-\mathrm{MgO}-\mathrm{SiO}_{2}-\mathrm{O}-\mathrm{CO}_{2}$. Am. Jour. Sci., v.275, p.143-162.

Taylor, B.E. and Liou, J.G. (1978) The low-temperature stability of andradite in C-O-H fluids. Am. Mineral., v.63, p.377-393.

Van Bemmelen, R.S. (1949) The Geology of the Indonesia, v. IA, 1st edition. Govt. Printing Office, The Hague, p.104-136.

2011년 12월 1일 원고접수, 2012년 1월 31일 게재승인 